\section{Netherlands Institute of International Relations 'Clingendael'}

Non-profit, independent think tank for international relations. Identifies and analyses emerging political and social developments for the benefit of government and the general public. Programme concentrations: diplomatic studies; European studies; security and conflict; international energy.

Address: Clingendael 7, 2597 VH The Hague, Netherlands.

Website: http://www.clingendael.nl

Director: Ron Ton.

\section{Peterson Institute for International Economics}

Founded 1981. Private, non-profit, non-partisan research institution devoted to the study of international economic policy. Research encompasses country and regional studies, debt and development, globalization, international finance and macroeconomics, international trade and investment, and US economic policy.

Address: 1750 Massachusetts Ave., NW, Washington, D.C., 20036-1903, USA.

Website: http://www.iie.com

Chairman: Peter G. Peterson.

\section{Pew Research Center}

Founded 2004. Non-partisan, non-profit fact tank that provides information on the issues, attitudes and trends shaping America and the world through public opinion polling, demographic studies, media content analysis and other empirical social science research.

Address: 1615 L St., NW, Suite 700, Washington, D.C., 20036,

USA.

Website: http://pewresearch.org

President: Michael Dimock.

\section{RAND Corporation}

Founded in 1948 out of US military research and development during World War II by Douglas Aircraft. Independent, nonprofit organization dedicated to promoting scientific, educational and charitable purposes for the public welfare. Research areas include health, education, national security, international affairs, law and business, and the environment. Houses three federally funded research and development centres sponsored by the US defence department: the RAND Arroyo Center, providing research and analysis for the army; the RAND National Defense Research Institute; and RAND Project Air Force.

Address: 1776 Main St., Santa Monica, CA 90401-3208, USA.

Website: http://www.rand.org

President: Michael D. Rich.

\section{Royal United Services Institute}

Founded 1831. Leading independent think tank engaged in cutting-edge defence and security research. The institution brings to the fore vital policy issues and offers expertise to policy makers.
Principal research areas: defence, industries and society; UK defence; terrorism; nuclear weapons and nuclear arms control; cyber-security; conflict, war and culture.

Address: Whitehall, London SW1A 2ET, UK.

Website: http://www.rusi.org

Chairman: Lord Hutton of Furness.

\section{Stockholm International Peace Research Institute (SIPRI)}

Founded in 1966 by the Swedish parliament. Independent international institute dedicated to research into conflict, armaments, arms control and disarmament. Compiles detailed studies on multilateral peace operations, military expenditure, arms transfers and arms embargoes.

Address: Signalistgatan 9, SE-169 70 Solna, Sweden.

Website: http://www.sipri.org

Interim Director: Ian Anthony.

\section{Transparency International}

Founded 1993. Non-partisan global civil society organization seeking to create change towards a world free of corruption. Global priorities: combating corruption in politics, public contracting and the private sector; international anti-corruption conventions; poverty and development.

Address: Alt-Moabit 96, 10559 Berlin, Germany.

Website: http://www.transparency.org

Chair of the Board of Directors: José Carlos Ugaz.

\section{Wilfried Martens Centre for European Studies}

Founded 2007. Political foundation of the European People's Party illustrating a pan-European mind set, promoting Christian Democratic, conservative and like-minded political values. It aims to inform decision-makers on new and effective policy options and seeks to raise public awareness of European citizens on the development of European integration. Research focuses on party structures and EU institutions, economic and social policies, EU foreign policy, environment and energy, values and religion, and new challenges to society.

Address: 20 Rue du Commerce, 1000 Brussels, Belgium.

Website: http://martenscentre.eu

Director: Tomi Huhtanen.

\section{Woodrow Wilson International Center for Scholars}

Founded in 1968 by an act of Congress as a memorial to former US president Woodrow Wilson. Non-partisan, it promotes and develops relations between policy-makers and academic scholars. Research covers most public policy areas, specializing in the field of international affairs.

Address: One Woodrow Wilson Plaza, 1300 Pennsylvania Ave., NW, Washington, D.C., 20004-3027, USA.

Website: http://www.wilsoncenter.org

Director: Jane Harman. 